\title{
Vulvar Squamous Neoplasm
}

National Cancer Institute

\section{Source}

National Cancer Institute. Vulvar Squamous Neoplasm. NCI Thesaurus. Code C40283.

A benign, precancerous, or malignant neoplasm that arises from the squamous

epithelium of the vulva. Representative examples include vestibular papilloma,

intraepithelial neoplasia, and squamous cell carcinoma. 